\title{
THEORETICAL EXAMINATION OF THE LONGITUDINAL BEHAVIOUR OF EMBEDDED RAILS
}

\author{
Zoltán MAJOR ${ }^{*}$
}

\section{Abstract}

The longitudinal behaviour of embedded rails significantly differs from that of ballasted or slab tracks with direct rail fastenings. As the ambient temperature rises and falls, rails expand and contract, thereby imposing stress on the channel and embedding compound. In the article the author presents the creation of a method that makes the calculation and the inspection of embedded rails simpler and closer to the everyday engineering mentality. The design process includes an analysis of the displacement and normal forces along a rail axis.

\section{Address}

1 Department of Transport Infrastructure, Széchenyi István University, Hungary, Egyetem tér 1, 9026 Győr, Hungary

* Corresponding author: majorz@sze.hu

\section{Key words}

- Embedded rail

- longitudinal behaviour,

- breathing length of ERS.

\section{INTRODUCTION}

The dilatational behaviour of embedded rails significantly differs from that of ballasted or slab tracks with direct rail fastenings (Ludvigh, 2002). Fig. 1 shows an embedded rail. While the initial flexible resistance is typical of the order of a $\sim 10 \mathrm{~mm}$ displacement, in the second and third cases, after a relatively small displacement of $(\leq 2 \mathrm{~mm})$, the linear flexible period is ideally followed by a plastic period (Nemesdy, 1966). The flexible longitudinal resistance of embedded rails has been investigated by Kulcsár and Major (2014) and the properties of railway ballast by Horvát and Fischer (2011a,b) and Fischer (2011).

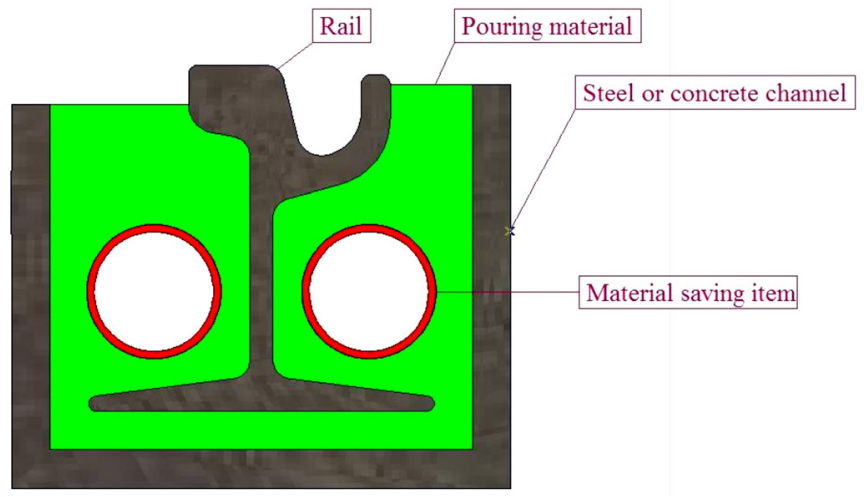

Fig. 1 Embedded rail structure.
This latter behaviour can be modelled with software that enables non-linear calculations (providing spring stiffness and limit force, see Tab. 1); and in practical calculations the flexible period can be ignored, and the plastic resistance of the ballast can be applied using well-known formulas (Lichtberger, 2005; Führer, 1978).

In the second graph there are force-displacement diagrams that are valid for ballasted tracks, slab tracks with direct rail fastenings according to EN 1991-2 and Calcada et al. (2009), and for embedded rail structures with a $30 \mathrm{kN} \cdot \mathrm{mm}^{-1} \cdot \mathrm{m}^{-1} / 2$ rail spring constant.

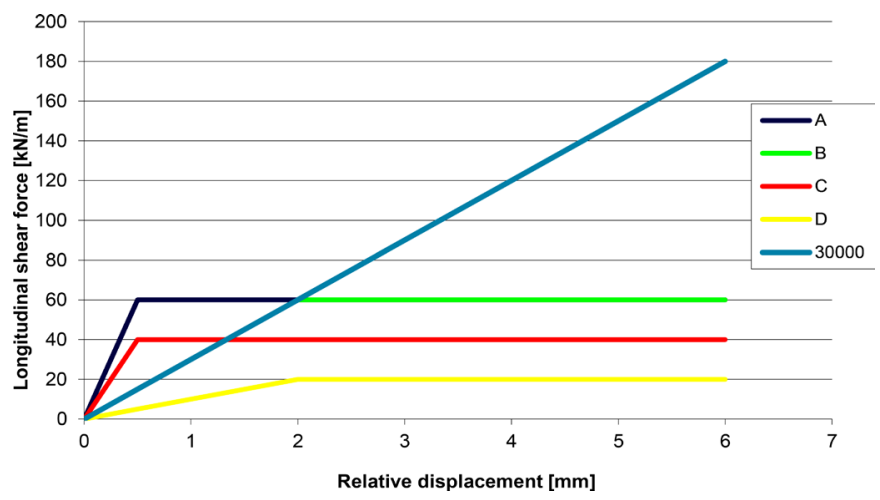

Fig. 2 Value of the shear resistance in the case of ballasted tracks, slab tracks with direct rail fastenings (Calcada et al., 2009), and embedded rail structures with 30,000 $\mathrm{kN.m}^{-2} / 2$ rails spring constant. Note: Figure 2 above applies to 2 rails! 
Tab. 1 Features of bilinear spring characteristics (Major, 2012; Major, 2013).

\begin{tabular}{|c|c|c|c|}
\hline Sign & Name & Spring constant $\left[\mathbf{k N . m ^ { - 2 } ]}\right.$ & Limit force [kN.m $\left.{ }^{-1}\right]$ \\
\hline A & Rail fastening on loaded track & 120,000 & 60 \\
\hline B & Ballast resistance on loaded track & 30,000 & 60 \\
\hline C & Rail fastening on unloaded track & 80,000 & 40 \\
\hline D & Ballast resistance on unloaded track & 10,000 & 20 \\
\hline
\end{tabular}

The two different kinds of dilatational behaviour (flexible and plastic) show a significant difference when the graphs of the dilatational forces and rail end movements are compared. The author calculated the behaviour of a $60 \mathrm{E} 1 \mathrm{rail}$ in the case of a $45{ }^{\circ} \mathrm{C}$ temperature change and applied a $10\left[\mathrm{kN} / \mathrm{m}^{-1} / \mathrm{rail}\right]$ value as plastic shear resistance. The author described the longitudinal stiffness of a rail embedding with a value of $5,000\left[\mathrm{kN} \cdot \mathrm{m}^{-2} / \mathrm{rail}\right]$. When the author established the length of the breathing period, a $0.01 \mathrm{~mm}$ displacement was set as a limit condition and not complete stillness (Kormos, 2002). The elasticity modulus of the rail is $206,000,000$ $\left[\mathrm{kN} . \mathrm{m}^{-2}\right]$; the value of the linear heat expansion factor is $1.2^{*} 10^{-5}\left[{ }^{\circ} \mathrm{C}^{-1}\right]$.

Figs. 3-6 below describe the changes in the dilatational forces and the displacement evolving along the length of the rail.

\section{ANALYTICAL DESCRIPTION OF LONGITUDINAL BEHAVIOUR}

A method for the analytical description of longitudinal behaviour can be found in the book "Modern Railway Track" $(2 \mathrm{~d} d$.) by Coenraad Esveld (2001).

Linear shear resistance is described by the following formula:

$$
\tau=\mathrm{ku}
$$

where:

$\tau$ : flexible shear/sticking resistance $\left[\mathrm{kN} \cdot \mathrm{m}^{-1}\right]$,

$\mathrm{k}$ : longitudinal spring constant $\left[\mathrm{kN} \cdot \mathrm{m}^{-2}\right]$,

$\mathrm{u}$ : displacement $[\mathrm{m}]$.

The differential equation describing the analysed problem is given by the following formula:

$$
\frac{d^{2} u}{d x^{2}}-\frac{k}{E A} u=0,
$$

where:

$\mathrm{x}$ : distance from the moving rail end $[\mathrm{m}]$;

E: modulus of elasticity of the rail material $\left[\mathrm{kN} \cdot \mathrm{m}^{-2}\right]$;

A: cross sectional area of the rail $\left[\mathrm{m}^{2}\right]$.

After solving the differential equation, we get the following equation for the displacement along the length of the rail (leaving out the deduction):

$$
\begin{gathered}
\mathrm{u}(\mathrm{x})= \pm \frac{\alpha \Delta \mathrm{T}}{\mu} \mathrm{e}^{-\mu \mathrm{x}}, \\
\mu=\sqrt{\frac{\mathrm{k}}{\mathrm{EA}}},
\end{gathered}
$$

where:

$\alpha$ : linear expansion coefficient of the rail material $\left[{ }^{\circ} \mathrm{C}^{-1}\right]$,

$\Delta \mathrm{T}$ : temperature change $\left[{ }^{\circ} \mathrm{C}\right]$.

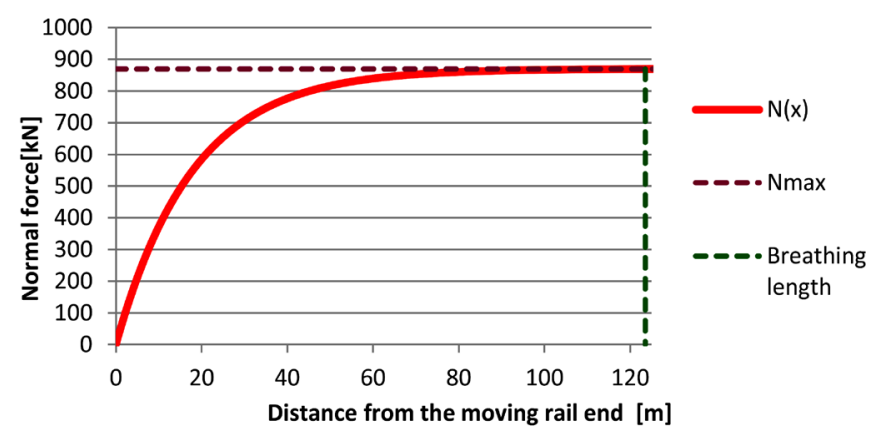

Fig. 3 The changes in the dilatational force along the length of the rail in the case of flexible shear resistance $\left(k=5,000 \mathrm{kN.m} \mathrm{m}^{-2}\right.$, "breathing length" $=123.500 \mathrm{~m}$ ).

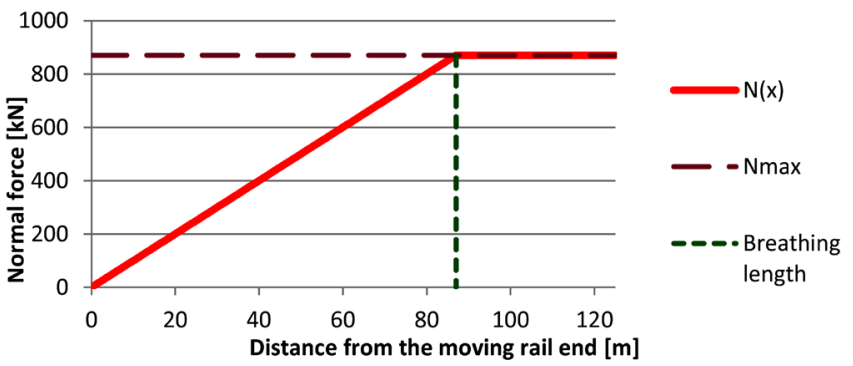

Fig. 4 The changes in the dilatational force along the length of the rail in the case of plastic shear resistance ( $p=10 \mathrm{kN} . \mathrm{m}^{-1}$, "breathing length" $=86.978 \mathrm{~m}$ ).

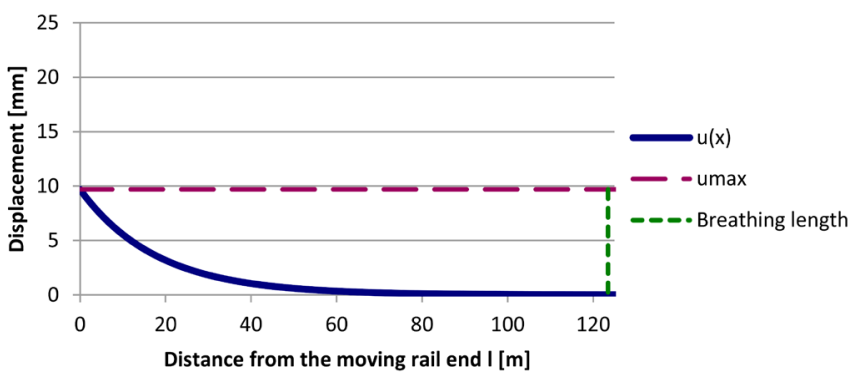

Fig. 5 The displacement of the rail along the length of the rail in the case of flexible shear resistance ( $k=5,000 \mathrm{kN.m}$-2, "breathing length" $=123.500 \mathrm{~m}$ ).

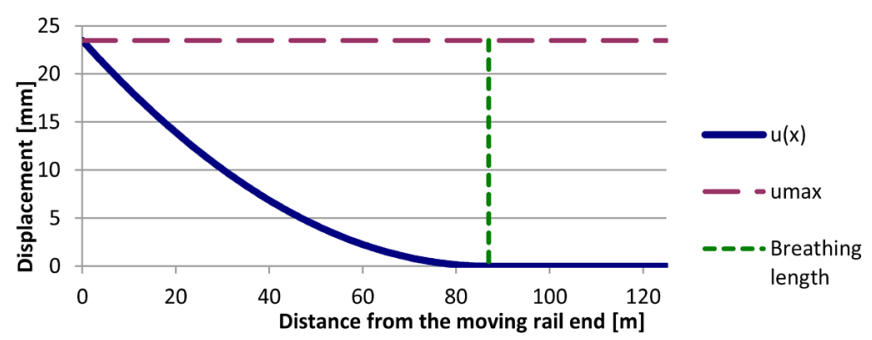

Fig. 6 The displacement of the rail along the length of the rail in the case of plastic shear resistance ( $p=10 \mathrm{kN} . \mathrm{m}^{-1}$, "breathing length" $=86.978 \mathrm{~m}$ ) 
The formula valid for a change in the normal forces:

$$
\mathrm{N}(\mathrm{x})= \pm \mathrm{EA} \alpha \Delta \mathrm{T}\left(1-\mathrm{e}^{-\mu \mathrm{x}}\right) .
$$

In engineering practice the analysis of two factors is essential. The first one is the size of the complete moving length of the rail (if there is a rail fracture, the breathing length is examined); the other one is the extent of the displacement of the moving rail end $\left(\mathrm{u}_{\max }\right)$.

To determine the breathing length in a closed form is impossible based on the above equation; the value of the maximum displacement can be determined from the equation below:

$$
\mathrm{u}_{\max }=\mathrm{u}(0)= \pm \frac{\alpha \Delta \mathrm{T}}{\mu}= \pm \frac{\alpha \Delta \mathrm{T}}{\sqrt{\frac{\mathrm{k}}{\mathrm{EA}}}}= \pm \alpha \Delta \mathrm{T} \sqrt{\frac{\mathrm{EA}}{\mathrm{k}}} .
$$

The author has created an Excel program based on the above formula, which can calculate and present the changes in the normal force and displacements along the rail. The rail's complete moving length can be calculated so long as the rail displacement reaches the limit value of $0.01 \mathrm{~mm}$.

For the purposes of validation, the author compared the results of the Excel program to the results of a Finite Element Model (FEM) calculation. The material characteristics, spring constant, and cross sectional data were as seen in Tab. 2. The results are summarized in Tab. 3.

Tab. 2 Input parameters of the model examined.

\begin{tabular}{|c|c|c|}
\hline $\mathrm{E}=$ & $206,000,000$ & {$\left[\mathrm{kN} \cdot \mathrm{m}^{-2}\right]$} \\
\hline $\mathrm{A}=$ & 0.007247 & {$\left[\mathrm{~m}^{2}\right]$} \\
\hline$\alpha=$ & $1.2 * 10^{-5}$ & {$\left[{ }^{\circ} \mathrm{C}^{-1}\right]$} \\
\hline$\Delta \mathrm{T}=$ & 45 & {$\left[{ }^{\circ} \mathrm{C}\right]$} \\
\hline $\mathrm{k}=$ & 10,000 & {$\left[\mathrm{kN} \cdot \mathrm{m}^{-2}\right]$} \\
\hline
\end{tabular}

Tab. 3 Results.

\begin{tabular}{|c|c|c|}
\hline & FEM calculation & Excel calculation \\
\hline Max. normal force $\mathrm{N}_{\text {max }}[\mathrm{kN}]$ & 806.16 & 806.16 \\
\hline $\mathrm{u}_{\max }[\mathrm{mm}]$ & 6.33 & 6.59 \\
\hline Breathing length $\mathrm{z}[\mathrm{m}]$ & $\sim 60.00$ & 79.50 \\
\hline
\end{tabular}

There is only one significant difference in the breathing length among the results above. The reason is that the FEM calculations do not produce the value of the breathing length directly; it can only be estimated with the help of a graph, where there is no substantial change in the normal force along the length of the rail. But the Excel program delivers an exact value based on the limit value of the displacement $(0.01 \mathrm{~mm})$. The normal forces at a breathing length of $60 \mathrm{~m}$ are very similar: in the FEM calculations it is $800.22 \mathrm{kN}$; in the Excel calculations it is $800.21 \mathrm{kN}$. So the Excel program devised by the author can be used for practical calculations.

\section{NEW FORMULAS FOR THE PRACTICE}

In the previous paragraph the analytical aspect of the dilatational behaviour of an embedded rail was described in the interrelation (6).
Using the "c" system factor for each rail profile, $u_{\text {max }}$ can be rewritten into this very simple formula:

where:

$$
\mathrm{u}_{\max }=\mathrm{u}(0)= \pm \mathrm{c} \Delta \mathrm{T} \sqrt{\frac{1}{\mathrm{k}}} .
$$

$$
c=\sqrt{\alpha^{2} \cdot E A} \text {. }
$$

The " $c$ " system factor depends on the material features $(\alpha, E)$ of the rail and the cross sectional area in each rail profile (A). In this form the relationship is simpler, and the need for calculations is much lower.

Tab. 4 shows the values of the „„" system factors for different rail profiles.

Tab. 4 Values of the "c" system factors.

\begin{tabular}{|c|c|}
\hline Rail profile & $\mathrm{c}\left[\mathrm{kN}^{0,5} \cdot{ }^{\circ} \mathrm{C}^{-1}\right]$ \\
\hline \multicolumn{2}{|c|}{ For heavy haul tracks } \\
\hline $49 \mathrm{E} 1$ & 13.662 \\
\hline $54 \mathrm{E} 1$ & 14.386 \\
\hline $60 \mathrm{E} 1$ & 15.084 \\
\hline \multicolumn{2}{|c|}{ For urban tracks } \\
\hline 51R1 & 13.933 \\
\hline $53 \mathrm{R} 1$ & 14.148 \\
\hline $59 \mathrm{R} 1$ & 14.928 \\
\hline $60 \mathrm{R} 1$ & 15.132 \\
\hline Ts52 & 14.182 \\
\hline 35GPB & 14.662 \\
\hline SA42-13 & 12.598 \\
\hline
\end{tabular}

Note: During the calculations the modulus of elasticity of the rail material was $E=206,000,000 \mathrm{kN} . \mathrm{m}^{-2}$. The linear expansion coefficient was $\alpha=1.2 * 10^{-5}{ }^{\circ} \mathrm{C}^{-1}$.

To determine the value of the complete moving length of the rail in the relation of the longitudinal spring constant is the next step. Considering a $45^{\circ} \mathrm{C}$ change in the rail temperature, the breathing length can be given with the following power function:

$$
\mathrm{z}(\mathrm{k})=\mathrm{ak}^{\mathrm{b}} \quad[\mathrm{m}]
$$

where:

$\mathrm{z}(\mathrm{k})$ : breathing length $[\mathrm{m}]$.

This general correlation can be derived from an examination of the results of the Excel calculations. The breathing length values were determined with different spring constants $(\mathrm{k})$ and different rail profiles. Parameters "a" and "b" are summarized in Tab. 5. The quality of the approximation is $\mathrm{R}^{2}=0.9999$.

This formula to be applied provides the calculations for the breathing length in a closed form, for which no possibility previously existed. Figs. 7-8 below describe the changes in the breathing length for heavy haul and urban tracks. 


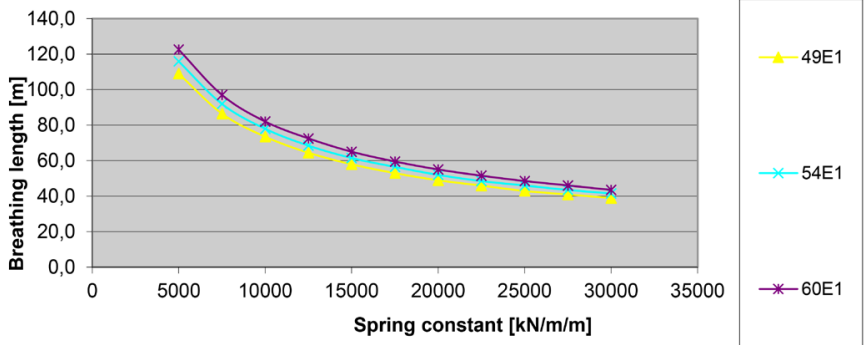

Fig. 7 Breathing length versus the spring constant for heavy haul tracks $\left(\triangle T=45^{\circ} \mathrm{C}\right)$.

Tab. 5 Values of the " $a$ " and " $b$ " factors of the power functions.

\begin{tabular}{|c|c|c|}
\hline Rail profile & $\mathrm{a}$ & $\mathrm{b}$ \\
\hline \multicolumn{3}{|c|}{ For heavy haul tracks } \\
\hline $49 \mathrm{E} 1$ & 14,738 & -0.5759 \\
\hline $54 \mathrm{E} 1$ & 15,716 & -0.5763 \\
\hline 60E1 & 16,598 & -0.5763 \\
\hline \multicolumn{3}{|c|}{ For urban tracks } \\
\hline 51R1 & 15,201 & -0.5767 \\
\hline 53R1 & 15,323 & -0.5757 \\
\hline 59R1 & 16,260 & -0.5753 \\
\hline 60R1 & 17,039 & -0.5787 \\
\hline Ts52 & 15,725 & -0.5781 \\
\hline 35GPB & 16,053 & -0.5762 \\
\hline SA42-13 & 13,629 & -0.5774 \\
\hline
\end{tabular}

\section{EXAMINATION OF THE POSSIBILITY OF POURING THE EMBEDDING MATERIAL FOR A RAIL CHANNEL ABOVE THE UPPER LIMIT OF A NEUTRAL TEMPERATURE ZONE}

The necessity of pouring the embedding material for a rail channel above the upper limit of a neutral temperature zone can happen in the summer season under the pressure of a construction deadline. Of course, the temperature regulations given in the technical instructions for the pouring material have to be maintained.

The previous equation in paragraph 3 is modified by a relation depending on a change in temperature over $45^{\circ} \mathrm{C}$. The " $\mathrm{t}(\Delta \mathrm{T})$ " factor makes a connection between the breathing length at a change in temperature over $45^{\circ} \mathrm{C}$ and the values at higher temperature changes.

$$
\mathrm{z}(\mathrm{k}, \Delta \mathrm{T})=\mathrm{z}(\mathrm{k}) \cdot \mathrm{t}(\Delta \mathrm{T})=\mathrm{ak}^{\mathrm{b}} \cdot \mathrm{t}(\Delta \mathrm{T}) \quad[\mathrm{m}] .
$$

In the formula above the only unknown factor is " $t(\Delta \mathrm{T})$ ", which was defined for more rail profiles. Based on the Excel calculations, the following formula was determined:

$$
\mathrm{t}(\Delta \mathrm{T})=\mathrm{p} \cdot \Delta \mathrm{T}+\mathrm{q} \quad[-] .
$$

The relations were determined for a $45^{\circ} \mathrm{C}<\Delta \mathrm{T} \leq 65^{\circ} \mathrm{C}$ rail temperature change (the temperature during construction is $+35^{\circ} \mathrm{C}$ and the weld breakage at $-30^{\circ} \mathrm{C}$; the temperature change is $\Delta \mathrm{T}=65^{\circ} \mathrm{C}$ ). Tab. 6 shows the "p" and "q" factor values for each rail profile.

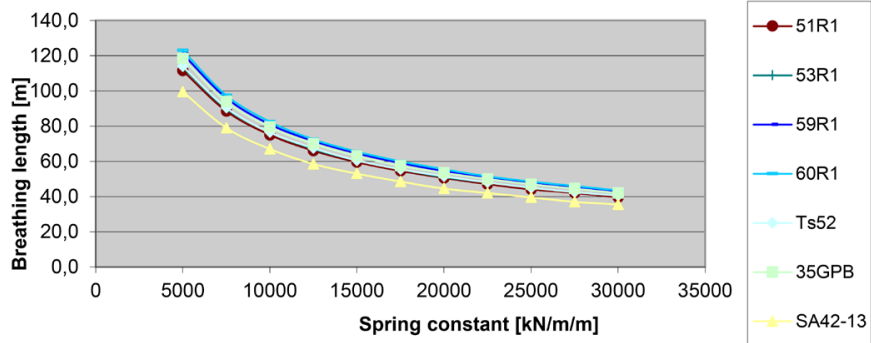

Fig. 8 Breathing length versus the spring constant for urban tracks $\left(\triangle T=45^{\circ} \mathrm{C}\right)$

Tab. 6 The values of " $p$ " and " $q$ "

\begin{tabular}{|c|c|c|}
\hline Rail profile & $\mathrm{p}$ & $\mathrm{q}$ \\
\hline \multicolumn{3}{|c|}{ For heavy haul tracks } \\
\hline 49E1 & 0.0030 & 0.8652 \\
\hline 54E1 & 0.0029 & 0.8706 \\
\hline 60E1 & 0.0030 & 0.8672 \\
\hline \multicolumn{3}{|c|}{ For urban tracks } \\
\hline 51R1 & 0.0030 & 0.8670 \\
\hline 53R1 & 0.0029 & 0.8724 \\
\hline 59R1 & 0.0029 & 0.8715 \\
\hline 60R1 & 0.0031 & 0.8608 \\
\hline Ts52 & 0.0029 & 0.8703 \\
\hline 35GPB & 0.0029 & 0.8704 \\
\hline SA42-13 & 0.0030 & 0.8680 \\
\hline
\end{tabular}

The author has also dealt with the practical problem of when the pouring of the rail channel happens over the upper limit of the neutral temperature zone. In this case there are two questions to answer:

1) What size is the opening gap in the case of a possible rail or weld breakage in the winter?

2) Is there any damage to the adhesion of the embedding compound (e.g., a tear from the channel wall) or in the embedding material itself (an internal shear fracture)?

Let us assume that the permitted value of the opening gap in the case of a rail/weld rupture cannot be over $20 \mathrm{~mm}$; this corresponds to a $10-10 \mathrm{~mm}$ rail end displacement. This can be considered as the permissible limit of any displacement.

According to the earlier studies, the damage to the embedding compound does not occur at a " $u_{\text {sup }}$ " displacement, so it can be considered as the permissible limit of any displacement for the embedding material. Using the former correlations:

$$
\begin{gathered}
\mathrm{u}_{\text {sup }}= \pm \mathrm{c} \Delta \mathrm{T} \sqrt{\frac{1}{\mathrm{k}_{\text {min }}}} \\
\mathrm{k}_{\text {min }}=\left( \pm \frac{\mathrm{c} \Delta \mathrm{T}}{\mathrm{u}_{\text {sup }}}\right)^{2}=\Delta \mathrm{T}^{2}\left( \pm \frac{\mathrm{c}}{\mathrm{u}_{\text {sup }}}\right)^{2} \\
\mathrm{f}=\left( \pm \frac{\mathrm{c}}{\mathrm{u}_{\text {sup }}}\right)^{2} \\
\mathrm{k}_{\text {min }}=\Delta \mathrm{T}^{2} \mathrm{f} .
\end{gathered}
$$


The "f" damage factor appearing in the formula above makes a connection between the rail profile and the maximum permissible rail end displacement. ("c" is the system factor). The maximum permissible displacement is $u_{\text {sup }}=7.5 \mathrm{~mm}$; there is no tearing of the embedding material from the rail or the channel wall, and the shear strength of the embedding compound is not exhausted. So a longitudinal lower limit for the spring constant value can be determined. If the spring constant is not lower than the $\mathrm{k}_{\min }$ value, the pouring material will not be damaged after a rail fracture in the winter time if the pouring was done at a higher temperature above the upper limit of the neutral temperature zone. Tab. 7 shows the "f" factor values for each rail profile.

If the value of the spring factor is higher than the necessary $\mathrm{k}_{\min }$, the structure is resistant to the given change in temperature in addition to the automatic fulfilment of the traffic security requirements. $\mathrm{k}_{\min }$

Note: Rail stresses must be checked in cases of the fulfilment of

\section{CONCLUSIONS}

In this article the author has presented the creation of a method that makes the calculation and inspection of embedded rails simpler and closer to the everyday engineering mentality. The other great advantage of the method created is that it does not require a FEM program; it is time-saving compared to FEM, because it requires no building of a model. Using the factors introduced during the deduction, the author has provided answers to practical problems such as the judgment for working out a neutral temperature zone.
Tab. 7 The values of the "f" factors.

\begin{tabular}{|c|c|}
\hline Rail profile & $\mathrm{f}\left[\mathrm{kN} .{ }^{\circ} \mathrm{C}^{-2} \cdot \mathrm{m}^{-2}\right]$ \\
\hline \multicolumn{2}{|c|}{ For heavy haul tracks } \\
\hline $49 \mathrm{E} 1$ & 3.3182 \\
\hline $54 \mathrm{E} 1$ & 3.6792 \\
\hline $60 \mathrm{E} 1$ & 4.0449 \\
\hline \multicolumn{2}{|c|}{ For urban tracks } \\
\hline 51R1 & 3.4512 \\
\hline 53R1 & 3.5585 \\
\hline 59R1 & 3.9617 \\
\hline 60R1 & 4.0707 \\
\hline Ts52 & 3.5756 \\
\hline 35GPB & 3.8218 \\
\hline SA42-13 & 2.8215 \\
\hline
\end{tabular}

\section{REFERENCES}

Ludvigh, E. (2002) Elastic behaviour of continuously embedded rail system, Periodica Polytechnica, Vol. 46, No. 1.

Nemesdy, E. (1966) Vasúti felépitmény (Railway Superstructure), Tankönyvkiadó, Budapest, Hungary [in Hungarian].

Kulcsár, N. - Major, Z. (2014) Rugalmas ágyazású kiöntött csatornás vasúti felépitmény (2. rész) - Rugalmas sincsatorna-kiöntések numerikus modellezése (Embedded rails (2.) - Numerical modelling of embedded rails), Sínek Világa, Vol. 56, No. 1, Budapest, Hungary [in Hungarian].

Horvát, F. - Fischer, Sz. (2011a) Investigations of the reinforcement and stabilisation effect of geogrid layers under railway ballast, Slovak Journal of Civil Engineering, Bratislava, Vol. XIX, 2011, No. 3, pp. $22-30$.

Horvát, F. - Fischer, Sz. (2011b) Superstructure stabilization of ballast bedded railway tracks with geogrids, Hungarian Journal of Industrial Chemistry, Veszprém, Vol. 39, No. 1, pp. $101-106$.

Fischer, Sz. (2011) Railway Superstructure Stabilization with Geosynthetic Layers, Transcom 2011, Zilina, Transcom 2011, 27-29 June 2011, pp. 35-38.
Lichtberger, B. (2005) Track Compedium, Eurailpress, Hamburg.

Führer, G. (1978) Oberbauberechnung (Superstructure calculation), Transpress, Berlin, Germany [in German].

EN 1991-2: Actions on structures - Traffic loads on bridges.

Calcada, R. - Delgado, R. - Campos e Matos, A. - Goicolea, J. M. - Gabaldón, F. (ed) (2009) Track-Bridge Interaction on HighSpeed Railways, CRC Press/Balkema, London, p. 68.

Major, Z.(2012) A vasúti híd és vágány kölcsönhatása (Interaction between a railway track and bridge), Sínek Világa, Vol. 54, No. 5, Budapest, Hungary [in Hungarian].

Major, Z. (2013) Special problems of interaction between railway track and bridge, Pollack Periodica, Akadémiai Kiadó, Budapest, DOI: 10.1556/Pollack.8.2013.2.11.

Kormos, Gy. (2002) Longitudinal behaviour of rail embedded in elastic material, Periodica Polytechnica, Vol. 46, No. 1.

Esveld, C. (2001) Modern Railway Track - $2 d$ Ed., MRT-Productions, Zaltbommel, p. 186. 